\title{
History and Symbols: \\ Lithuanian and Central European Cinema of the 1960s
}

\author{
ANNA MIKONIS-RAILIENE்
}

[1]Central Europe is not a state: it is a culture or a fate. Its borders are imaginary.

Milan Kundera, 1984

\section{Introduction}

It is not an easy task to write about Lithuanian cinema of the 1960 . Cinema, having the status of an official art and unable to fully function in underground conditions, found itself in an unenviable position. The ideological pressure that Lithuanian cinema was under during the Soviet period has been an influential factor as to why important and significant works on Lithuanian cinematography have yet to be written and have failed to receive their deserved place in Lithuanian culture. The politically-motivated context of Soviet cinema does not allow Lithuanian cultural historians the chance to examine this period of cinema on a deeper level. While the Polish school of cinema is understood as an

[1] This research was completed as part of the project The Lithuanian cinema (1956-199o). Creators. Films. Contexts, carried out by the Vilnius University and funded by the European Social Fund under the Global Grant measure (Grant No. VP1-3.1-SMM-07-K-02-019).

[2] J. Žalman, Films and Filmmakers in Czechoslovakia, Prague 1968, p. 9.

[3] The first Lithuanian feature film Sunrise Near the Nemunas (Aušra prie Nemuno, 1953) was made by Soviet director Aleksandr Faintsimmer. This propaganda film with an anti-religious theme talked about the collectivization of a Lithuanian village. The film was not well-received by the general public. This circumstance seemed to throw an ideological shadow on the entirety of future Lithuanian films.

[4] D. Iordanova, Cinema of the Other Europe: The Industry and Artistry of East Central European Film, London, New York 2003, p. 14. important part of national culture that is deeply embedded in the collective consciousness, and the new wave of Czechoslovakian film grew out of a cinema with strong national traditions, as Jan Žalman writes,[2] Lithuanian cinema has not become an important part of cultural and national consciousness or the subject of serious reflection among society at large. The evaluation of Lithuanian cinema is greatly influenced by its history. Lithuanian cinema, which essentially did not exist during the interwar period, talked with the voice of a totally foreign ideology after Lithuania was incorporated into the USSR. The new Soviet government "brought in" the new art of cinema.[3] Also lacking is a closer look at Lithuanian cinema from the internal viewpoint of Lithuanian national cinematography. During the Soviet period, Lithuanian cinema developed as a product of Soviet cinema, closely watched by Soviet critics and censors in Moscow. As Dina Iordanova has remarked:

[...] the study of Soviet cinema has been more or less reduced to the study of Russian cinema, which scholars almost exclusively treat as synonymous with Soviet cinema. It is extremely rare to see writing on the cinemas of Ukraine, Belarus, the republics in the Caucasus (Armenia, Georgia, Azerbaijan) or the Baltics (Latvia, Lithuania, Estonia). Where do these cinemas belong today one wonders? They are left in a sort of vacuum - the Russian specialists are no longer interested in them, and scholars of 'Eastern Europe', that other periphery of Russian influence, think they are in the 'realm' of the Soviet specialists.[4]

Lithuanian cinema is researched and written about from the viewpoint of this historical-cultural context of Soviet cinema. But if we would touch down from this bird's eye view and take a closer look at the reality, we would see that 
Lithuanian cinema is markedly different from Soviet cinematography. As Bjorn Ingvoldstad states, despite Soviet occupation, Lithuanian cinema existed, was made, and showed various aspects unique to it, though Lithuania did not exist as a state.[5] However, the nation and its culture did exist, though it was in the structure of a foreign empire. Lithuanian cinema, chained to an ideological doctrine, as I will attempt to show, was strongly tied to cinematic ideas from another part of Europe. No doubt this relatively small-scale cinematography, under the watchful eye of Moscow and almost unknown beyond the borders of the Soviet Union, could not make an impact on European cinema at the time; however, it adopted much from the trends that were dominant at the time. We can appreciate the Lithuanian films made in the 1960 s as a unique phenomenon, the essence of which is comprised of unique, artistic and cultural traditions together with the necessary context of a national history, culture, and mentality permeated with the artistic traditions of European cinema.

This text discusses the most creative period of Lithuanian cinema: the 196os. This analysis is an attempt to frame the historical, artistic, and thematic changes in Lithuanian cinema within the context of the changes that occurred in Polish, Hungarian, and Czech cinema during the 1960s. Revealing the strength of the cinematic influence of the neighbouring countries of Central Europe allows us to show the exceptional nature of Lithuanian cinema in the context of the policy on the arts in the Soviet Union. The cinematographic context of Central European countries provides an opportnity to look at 196os Lithuanian cinema from another perspective. As Antonin Liehm has remarked, "whenever an aesthetic viewpoint is dictated from above, the only way to step out of this circle is by means of a different aesthetic viewpoint $[\ldots]$...[6]

The themes of Lithuanian feature films and the unique aspects of its cinematic language, as well as some of the films from the new wave in Polish, Czechoslovakian, and Hungarian cine- ma will provide context for discussing Lithuanian cinematic works. In analyzing Lithuanian cinema, I will focus attention on the most representative films of the 1960 s. I will discuss in greater detail the most important and interesting films that garnered international recognition: the cycle of short stories entitled Living Heroes/Gyvieji didvyriai, the artistic director of which was Vytautas Žalakevičius, along with his epic work Nobody Wanted to Die/Niekas nenorejo mirti. I will also mention films impacted by censorship (for example, Feelings/Jausmai directed by Almantas Grikevičius and Algirdas Dausa.) or films that are well-known only to Lithuanian audiences (A Staircase to the Sky/ Laiptai i dangu directed by Raimondas Vabalas).

What was Lithuanian cinema like when it was locked in the clutches of ideological censorship? What themes did it examine? Despite censorship, did it achieve the same level as the cinema of the Poles, Czechs, and Hungarians during the same period? We will attempt to answer these questions.

\section{A new generation of filmmakers - influences or inspirations? [7]}

One could say that one common trait of 1960 s European cinema was the debut of works from young talented directors during almost

[5] B. Ingvoldstad, „The Paradox of Lithuanian National Cinema", [in:] Via Transversa: Lost Cinema of the Former Eastern Bloc, Place and Location: Studies in Environmental Aesthetics and Semiotics VII , ed. Eva Näripea, Andreas Trossek 2008, pp. 137-154.

[6] A.J. Liehm, The Polititics of Culture, trans.

P. Kussi, New York 1973, p. 171.

[7] This text will not look at the national cinematographic influence of the Soviet Union on 196os Lithuanian film. Without a doubt, the Georgian, Ukrainian and Russian New Wave of the 196os had a certain effect on the work of Lithuanian directors. However, this is an entirely different topic. One should note that today, the term "Soviet film" demands new theoretical considerations because this concept in essence was artificial, and of a political nature, and the centralised cinematographic policy strove to strongly 
the same period. These young directors had successful starts not only in countries with long-standing cinema traditions like France, England and Italy, but also in Central and Eastern European countries. A series of talented directors arose in Polish, Czechoslovakian, and Hungarian cinema who earlier did not have any opportunities to make their debut. The fermentation of artistic groups was started by the Polish film school, and afterwards was continued by the Czechoslovakian and Hungarian New Wave. A new generation of directors also debuted in Lithuanian cinema. The new film movements, with Lithuanian film among them, expressed the goal of a new generation of freedom and important aesthetic changes in terms of the dominant traditions. As Jan Kadar wrote, "young, inexperienced, however full of talent and intelligence, they turned away from what was, and suddenly did great works".[8] The formation of new currents in cinema was

curb and level the separate nature of national film studios and their work (cf. D. Dabert, "Czy warto pisać dzieje kina Europy Środkowo-Wschodniej?", Porównania 2010, no 7, p.132)

[8] A.J. Liehm, "Filmy pod specjalnym nadzorem. Doświadczenie czechosłowackie", trans. A. Jagodziński, P. Krauze, T. Grabiński, Film na Świecie 2003, no. 404, p. 54.

[9] Cf. J.Wojnicka, "Kino krajów Europy Środkowej”, [in:] Słownik wiedzy o filmie, eds. J. Wojnicka, O. Katafiasz, Warszawa, Bielsko Biała 2008, pp. 163-171.

[10] A. Streikus, "Pagrindiniai sovietų valdžios kultūrinès politikos bruožai Lietuvoje 1940-1990", [in:] Lietuvos kultūra sovietinés ideologijos nelaisveje 1940-1990, ed. J. Romualdas Bagušauskas, A. Streikus, Vilnius 2005, p. 19.

[11] The model for controlling Lithuanian cinema essentially was a reflection of the structure of cinema in the USSR. Starting in 1953, the Ministry of Culture of Soviet Lithuania was in charge of cinema, which was a model based on the example of the Ministry of Culture of the USSR. In 1963 , cinema issues were dealt with by the USSR State Committee for Cinematography (Goskino), and in Lithuania by the State Committee for Cinematography under the Council of Ministers of the LSSR. connected to political changes. A turning point occurred in 1956 when Nikita Khrushchev gave a speech denouncing the crimes of the Stalin regime at the 2oth Congress of the Communist Party of the Soviet Union. It was not yet a real thaw, the name of which was provided by Ilya Erenburg's book; however, it was already possible to see change. The denouncing of the Stalin myth, the beginning of the Khrushchev era, and the decisions of the 2oth Party Congress also had an impact on Central Europe. The political thaw and attempts to reject Socialist Realism principles in art led to new phenomena appearing in the cinematography of Poland, Czechoslovakia, Hungary, and Lithuania, with film directors urging people to look deeper into the reality that was being filmed.[9] In Lithuania, which at the time was one of the 15 Soviet Socialist Republics, the processes of the thaw started at the end of the 1950s. It was then that for the first time the cultural weekly Literatūra ir menas (Literature and Art) organised a discussion where writers and artists came out in favour of greater creative freedom in depicting everyday reality. As historian Arūnas Streikus says, the Lithuanian communist government endorsed creative forms that modernised Socialist Realism, with the First Secretary of the Communist Party Antanas Sniečkus at the forefront.[10] The much softer attitude of the communist government had a great impact on the expansion of film. However, it has to be emphasized that control of "the most important of the arts" in the Soviet Empire was far and away much stricter. Lithuania, like Latvia and Estonia, was not an independent state. It had become part of the common space of Soviet ideology. The official language was declared to be Russian, and all of the "bourgeois" past was thrown out of our history, while our national symbols - our flag and hymn - were replaced with new ones. Lithuanian culture, as well as cinema, constantly did a balancing act between the people in power in Moscow, who strove for as much influence in Soviet culture as possible, and the local Lithuanian ruling elite.[11] The success or failure of Lithuanian filmmakers 
both in the press and at festivals was reported as the successes or failures of Soviet film, and not Lithuanian film.[12] As Janusz Gazda writes, Lithuanian films (as all other films made within the territory of the USSR), were shown in Poland (and other countries, as well as in Soviet republics), and dubbed in Russian. In this way, they were considered a part of the Russian-speaking "Soviet culture." [13] However, despite outside control, concepts and ideas were born in this circle of people in which the quality and level of Lithuanian film became their most important priority. The only creative studio in Lithuania became Lithuanian Film Studios. It was this collective of artists that provided the innovative solutions of Lithuanian filmmakers in the 196os. The tradition of Lithuanian poetic cinema grew from this artistic soil in the 196os.[14]

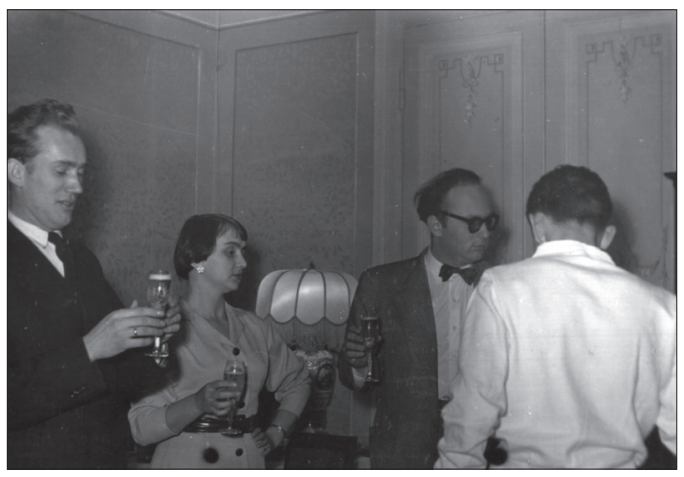

Jerzy Hoffman (second from the right) at a party after the defense by Vytautas Žalakevičius of his diploma work, 1955.

After the end of the ideological film news reels and Socialist Realist films that came from directors from the Mosfilm and Lenfilm film studios, there were films that appeared in Lithuanian cinema that garnered attention not only in Lithuania, but also in Europe, for their unique and fascinating visual form. The $1950 \mathrm{~s}$ was a period of successful debuts for Lithuanian cinema. At this time a very promising new generation of filmmakers who had finished their studies at the All-Union State Institute of Cinematography (VGIK) in Moscow and were well-rounded, began to say they desired to create a different model of cinema. In writing about his generation, Vytautas Žalakevičius said that "[w]e were young [...]. It appeared to us that we will live forever. And we'd work a long time. People wanted to produce, write, paint. And we were happy, speaking with an (almost) open mouth." [15] This new generation of filmmakers returned from Moscow to Lithuania full of hope and energy. All made their debut at Lithuanian Film Studios, their home studio, creating documentaries and feature films. Vytautas Žalakevičius' feature film debut was Adam Wants to Be a Man/Adomas nori būti žmogum (1959). Arūnas Žebriūnas came into film with his short film The Last Shoot/ Paskutinis šūvis,(1960), which Marijonas Giedrys also did, debuting with the short film We Dont Need Anymore/Mums nebereikia, (1960). Raimondas Vabalas, encouraged by his teacher Lev Kuleshov, debuted with his diploma work Steps at the Night/ Žingsniai nakti (1962). Almantas Grikevičius started his directing career with a poetic documentary impression about Vilnius in Time Walks through the City/Laikas eina per miesta, (1966). Alongside the debuts of directors, a number of young cameramen began their careers at the same time, including Jonas Gricius, Donatas Pečiūra, Algirdas Araminas, Algimantas Mockus and Jonas Tomaševičius.

[12] The films were dubbed in Russian (the Lithuanian version was distributed in Lithuania only). Lithuania Film Studios' documentation and correspondence as well as the script were translated into Russian. What is painful is that today we do not have the outtakes and material (negatives and phonograms) in Lithuania. The works of Lithuanian directors that were made in Soviet Lithuania are preserved in the Gosfilmofond of Russia.

[13] J. Gazda, "Za oknem krzyży", Kwartalnik Filmowy 2007, no 57-58, p. 242.

[14] Vide A. Mikonis, Poetycki kinematograf. Nurt artystyczny w kinie litewskim, Warszawa 2010.

[15] V. Žalakevičius, Aš nežinau, Vilnius 1997, p. 265. 
What created the shape of cinema for these young Lithuanians was their years studying film in the metropolitan atmosphere of Moscow. This provided VGIK students with the chance to get acquainted with films from around the world, which clearly impacted their creative development. This educational institution functioned as a melting pot of various nations and cultures. "Soviet film-system policy", as Estonian film researcher Eva Näripea says, "promoted the crossing of internal borders between the republican states of the Union by encouraging and sometimes imposing co-operation between the Socialist Republics, as well as with other members of the Eastern bloc, and by centralizing professional training." [16] It was during his studies at VGIK that Žalakevičius became acquainted with fellow students Jerzy Hoffman and Márta Mészáros, and operator Donatas Pečiūra had long talks into the night with Jerzy Grotowski, as well as with operator Roman Farat, with whom he shared a dormitory room. The studies of both Žalakevičius and Hoffman were supervised and overseen

[16] Cf. Eva Näripea, "National Space, (Trans) National Cinema: Estonian Film in the 1960", [in:] A Companion to Eastern European Cinemas, ed. Anikó Imre, Oxford 2012, pp. 244-264. [17] Jerzy Hoffman's and Jerzy Skórzewski's documentary film which began the "Black Series" in Polish cinema, and also inspired Vytautas Žalakevičius' creative conception. In the film Look Out! Hooligans an unseen narrator takes a newspaper from the hands of an elderly man and says: "Look, you have to look! A crime was committed just a step away from you. That is where your indifference is taking you." In Žalakevičius' film, the main character stands passively under a tree and sees how nearby two young hooligans kill a passer-by with a knife. The voice of a judge asks: "Why did you stand passively under the tree while a man was killed near you?" "It was raining," says the witness to the event.

[18] A. Žebriūnas, "Rinkdavausi siužetus, kurie pramuštų lubas ir skristu ị begalybę...”, Kinas 2013, no. 4(324), p. 49.

[19] Film industry researcher Kristin Roth-Ey determined, based on a directive of the Central Committee, that the USSR purchased 63 films by Mikheil Chiaureli; however it seems that Stalin's favourite director did not have any great influence upon these young directors. Both finished their studies in 1955, and from that time they were bound by friendship and common creative ideas. Žalakevičius, who was influenced by the main ideas of Jerzy Hoffman and Jerzy Skórzewski's documentary film debut Look Out! Hooligans/Uwaga, chuligani!, directed the innovative feature film The Chronicle of One Day/ Vienos dienos kronika in 1964, in which the same main motif was expanded upon.[17]

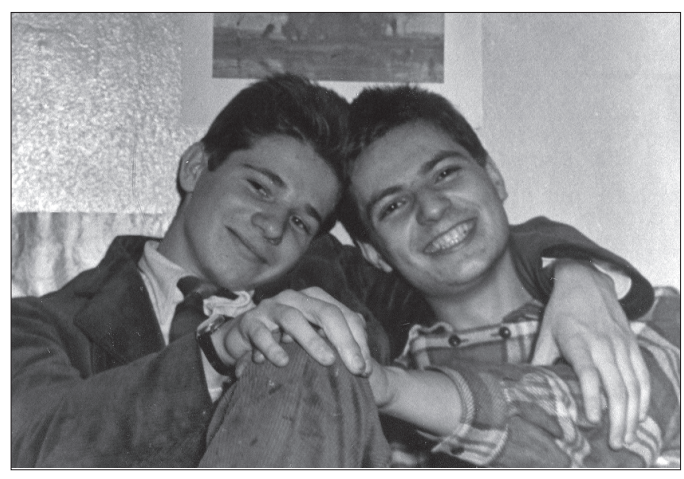

Donatas Pečiūra (left) and Roman Farat during their studies at VGIK, 1956.

The interest in Central European film was strengthened by foreign trips (though few and strictly controlled) and personal acquaintances. During his studies, Vytautas Žalakevičius became acquainted with Andrzej Wajda, while Almantas Grikevičius became acquainted with Krzysztof Zanussi and Polish film critic Janusz Gazda. Arūnas Žebriūnas saw the work of Miloš Forman at the Karlovy Vary Film Festival, and also met there Karel Kachyna. Years later, Žebriūnas remembered that "I liked the films of Forman and Kachyna. Roman Polanski's Two Men and a Wardrobe made a big impression on me. The scene in which two men carry a wardrobe from the sea is the most beautiful in cinema history. It's simply a masterpiece." [18]

Polish and Hungarian cinema reached the cinema halls of the Soviet Union,[19] as well as 
Lithuania, during the 196os. Vladimir Baskakov, the most important censor of the "most important of the arts", remembers that "the State Cinema distribution organizations were afraid neither of Wajda's A Generation, Ashes and Diamonds, nor Kawalerowicz's Mother Joan of the Angels, though blunt dissatisfaction was expressed in official circles as well as in the press at the time." [20]

In this way, young filmmakers were knowledgeable of what was going on in the world cinematography, as well as that of neighbouring countries. Lithuanian filmmakers at the time were influenced not only by Neo-Realism (Vytautas Žalakevičius made his feature-length debut film Adam Wants to Be a Man under its influence), but also by the French New Wave (felt in the work of Almantas Grikevičius), as well as the achievements of Polish, Czech, and Hungarian film. Almantas Grikevičius admitted after a number of years that "I always liked Polish film. It was close to me. And not just for me, but for other Lithuanian directors. Most likely it has a lot to do with our common history, especially in Wajda's films." [21]

The first films that the VGIK graduates were able to realise at Lithuanian Film Studios already bear witness to the important aesthetic changes taking place in the modest tradition of Lithuanian film. The debuts of Lithuanian directors meant a new turning point in Lithuanian cinema. In writing about Living Heroes, Nobody Wanted to Die, and Steps in the Night, Russian film researcher Andrei Shpagin wrote "Metaphysics in Soviet cinematography started from Lithuanian cinema [...] Lithuania discovered the kind of paths of the artistic expression of cinema that Soviet cinema couldn't even dream of at all [...] here nothing was clear, here everything was mysterious and deceptive. [22] A vivid trait of cinema at the time was an attempt to reject the doctrine of Socialist Realism by making film genres that up until then had not been tried, looking for new directorial and camera tools for cinematic expression, and striving to find new roles for actors, and unexpected scenographic and musical solutions.
The crux of the films' structure was the individual characters, while the stories that were told and the dramatic fates of the people were seen through the personal experience of the individual. One could say that these new filmmakers embodied the dynamism and freshness of the New Wave in Lithuanian cinema that had spread across Europe at that time. Their debut coincided with the creative turning point that was represented in Polish cinema by Andrzej Wajda, Jerzy Kawalerowicz, and Andrzej Munk, in Czech and Slovak cinema by Štefan Uher, Miloš Forman, Jiří Menzel, Jan Němec, and in Hungarian cinema by István Gaál, István Szabó, and Sándor Sára.

The beginning of the 1960 s is tied to a generational change that led to a new model for cinema. The allusional language in the films of Vytautas Žalakevičius, Arūnas Žebriūnas, Almantas Grikevičius, and Raimondas Vabalas began to talk about Lithuanian history, while the ideological context of film was replaced by a multi-level form of cinema. The poetic nature of Lithuanian film included its interesting visual form, spaces full of secret signs and symbols, the dialogues imbued with existential anxiety, and the domination of historical themes. All of these traits set Lithuanian film apart from the work of other Soviet republics. As Almantas Grikevičius said:

made in foreign countries (in Poland, Hungary, and Czechoslovakia), 113 films made abroad in 1958, and had plans to buy more than 150 films from abroad in 1960 (Cf. K. Roth-Ey, Moscow Prime Time. How the Soviet Union Built the Media Empire that Lost the Cultural Cold War, New York 2011, p. 36).

[20] V. Baskakov, Kak zamorozili kinematograf „ottepieli”, [in:] Kino i vlast': Sovetskoye kino: 1965-1985 gg., ed. V. Fomin, Moskva 1996, p. 132. [21] A. Grikevičius, „Didieji apsisprendimai: Maskva-Leningradas-Vilnius-Maskva", [in:] Epizodai paskutiniam filmui. Režisierius Almantas Grikevičius, ed. L. Kaminskaitė-Jančorienè, A. Švedas, Vilnius 2013, p. 57. [22] A. Shpagin, „Sumerki. Zametki o litovskom kino", Kinoforum 2008, no 2, p.48. 


\section{VARIA}

[...] during my study years, the 'pribaltai' [those from the Baltic region] seemed like foreigners for many studying at VGIK; however, it was hard to say anything more about us, because no one really knew, neither who we were, nor what we could do. Some time later, when we began to work, it became clear that the 'pribaltai' set themselves apart with the themes they chose and their way of thinking. In our films, above all there was a deeper look into the life of our country, and often in them there were historical themes touched upon, the partisans were talked about.[23]

Let us take a closer look at the phenomenon of Lithuanian film of the period.

\section{Encrypted images}

The first Lithuanian film to garner international success was one made by a group of young filmmakers who were making their debut film at Lithuanian Film Studios. The year 1959 saw the making of the short story cycle Living Heroes at Lithuanian Film Studios; the film was praised by both viewers and critics as an example of an especially mesmerizing and subtle form of poetic cinema. The film was comprised of four short stories: We Don't Need Anymore/Mums nebereikia (directed by Marijonas Giedrys, cameramen Donatas Pečiūra, and Robertas Verba), A Nightingale/Lakštingala (directed by Bronius Bratkauskas, cameraman Algirdas Araminas), The Last Shot/Paskutinis šūvis (directed by Arūnas Žebriūnas, cameraman Jonas Gricius) and Gyvieji didvyriai/Living Heroes, (directed by Vytautas Žalakevičius, cameraman Antanas Mockus). According to the concept of the artistic director, the film provided portraits of the most important periods in Lithuanian history: the period of serfdom (We Don't Need Anymore), the German occupation (A Nightingale), the post-war years (The Last Shot) and the "happy" Soviet reality (Living Heroes). However, there was an idea hidden under this official historical costume to tell the truth about the difficult post-war times of a Lithuania in a web of Soviet ideology. The dominant thematic focus of these short cinematic tales was Lithuania as a symbol of a land subjugated politically. The image of a subjugated land was most vividly revealed in the short stories We Don't Need Anymore, A Nightingale, and The Last Shot. We will briefly look at these especially lyrical short stories that have a poetic form.

The first short story We Don't Need Anymore starts off with images of the poor pre-war Lithuanian countryside. It is a story about a village boy named Juozukas (played by Nerijus Narkis), who was employed by a rich farmer as a shepherd. Upon his arrival to the farm, he finds out that he is not needed anymore. The image of the village boy Juozukas, whose fate is decided by someone else, speaks in a believable manner about Soviet Lithuania. This image was supplemented by the tone of the entire film, the grey images, and the grey contours of the landscape and costumes. The camera, in slow motion emphasizes the tragedy of the little boy's story. In the scene, where the child says goodbye to his home, the camera is pointed upwards, showing the receding road to the village and the fields in the distance engulfed in mist, emphasizing the utter hopelessness of a peasant's existence in a world of injustice, and, at the same time, providing an eloquent symbol of captivity.

The film A Nightingale is based on a short story by the Lithuanian writer Petras Cvirka, and is the second part of a four-film cycle. A blonde boy, who is able to imitate the sound of a nightingale, is forced to show a platoon of German soldiers hiding in the forest the way to a settlement unknown to them. The platoon is struggling as it moves along the forest road. The camera closely follows the tired faces of the soldiers slogging through the heat. At times the intensive observation of the camera creates the impression that it is examining the life of people lost and hopeless in the face of nature. After this difficult forest journey, Nightingale (Vytautas Buizys) takes the platoon straight to a group of armed partisans.

[23] A. Grikevičius, op.cit. p. 58. 


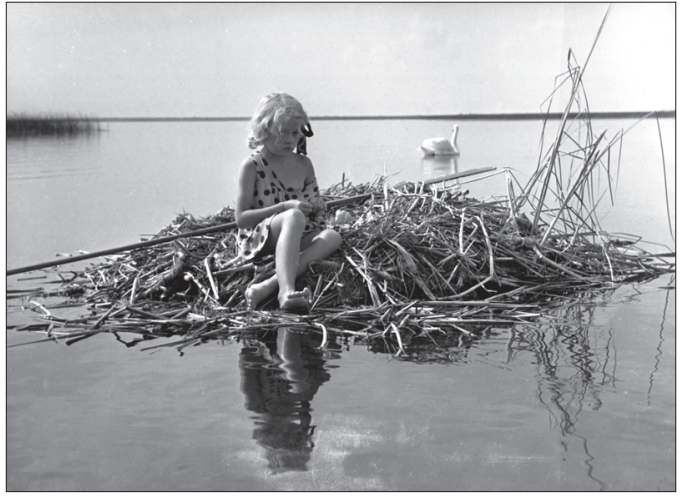

Laima and the swan nest, The Last Shot, directed by A. Žebriūnas.

The main characters of the short The Last Shot tale are a fair-haired girl named Laima (Živilè Jakelaitytè), who lives in an idyllic village near a lake and takes care of the swans, and a tired man hiding in the forest (Bronius Babkauskas). The nest of the swan becomes the girl's home. It is where she spends her nights and meets the morning. In the morning when she wakes up, she begins to play with the bullets she has taken from the man. She throws them into the water, while the man, who has seen this, begins to collect them, wading through the swamp. This meeting ends tragically: the man accidentally begins to sink in the quagmire, tries to get out from the mud, and shoots and kills Laima. The camera slowly zooms out from the nest with the dead girl, gradually pointing skyward, with swans flying silently overhead in the sky.

The plot is engaging because of the associative way it was edited, contrasting the images of a Soviet tank and the little girl, a crown (a symbol of innocence) and barbed wire (a sign of Soviet reality), the swan nest with Laima living in it (a symbol of a safe haven) and the swamp, where a hiding soldier dies. Her character was inspired by the mythological Lithuanian goddess Laima. The Laima who cares for the swans is expressively tied to the fertility of this mythological goddess, a symbol of rebirth and new life. The image of a fair-haired girl who had the mythological name of Laima was no coin- cidence.[24] Arūnas Žebriūnas said in speaking about his creative concepts at the time that "I felt a huge need to turn back to mythological generalizations and symbols. I looked for the roots of Lithuanian culture in Lithuanian mythology." [25]

The innovative nature of the cycle Living Heroes was hidden in its poetic mood and specific visual expression, sound, and editing techniques. This was expressed by the author's ability to consider the semantic organization of the work down to the smallest detail. The disclosure of the image's narrative functions, the economical use of words, and the montage of allusions allowed viewers to understand the film's poetic etudes as a multi-layered metaphor. Symbols such as the image of the child became an instrument for recognising the history of post-war Lithuania.

The formalism of the short story The Last Shot, and the poetic symbolic image of Laima and her swan, intentionally or not, is tied to the innovative poetic etude about freedom called The White Dove/Holubice by František Vláčil, the premiere of which also took place in 1960. The film's visual narrative, a space distanced from reality, austere dialogue, an atmosphere of sadness, a drowning mood, and lyrical and symbolic images link this Lithuanian work with Vláčil's poetic etude. According to Peter Hames, it is a manifestation of simple humanist ideas, embedded in an expanded aesthetic structure, which does not so much construct the plot as it gives rise to poetic associations, [26] which also became an aesthetic manifesto for young Lithuanian filmmakers.

The creation of four short stories in 1959 was a revolutionary concept by Lithuanian Film Studios. The uncomplicated scriptwriting of the film, reminding one of poetic miniatures,

[24] Vide A. Mikonis-Railienè, "Poezja, mitologia i ideologia. Obraz dziecka w tworczości Arūnasa Žebriūnasa", Kwartalnik Filmowy 2013, no. 81, p. $151-167$.

[25] A. Žebriūnas, op.cit. p. 63.

[26] Cf. P. Hames, The Czechoslovak New Wave, London 2005, p. 35. 
did not demand a long text, and also made it possible to avoid the strict checking of the censors and provided a chance to employ almost all the directors who were working at Lithuanian Film Studios at the time. The 1960 short story cycle won the main prize at the Twelfth Karlovy Vary International Film Festival, the FIPRESCI award from the International Federation of Film Critics, and the main Great Amber Award at the Second Baltic Film Festival.

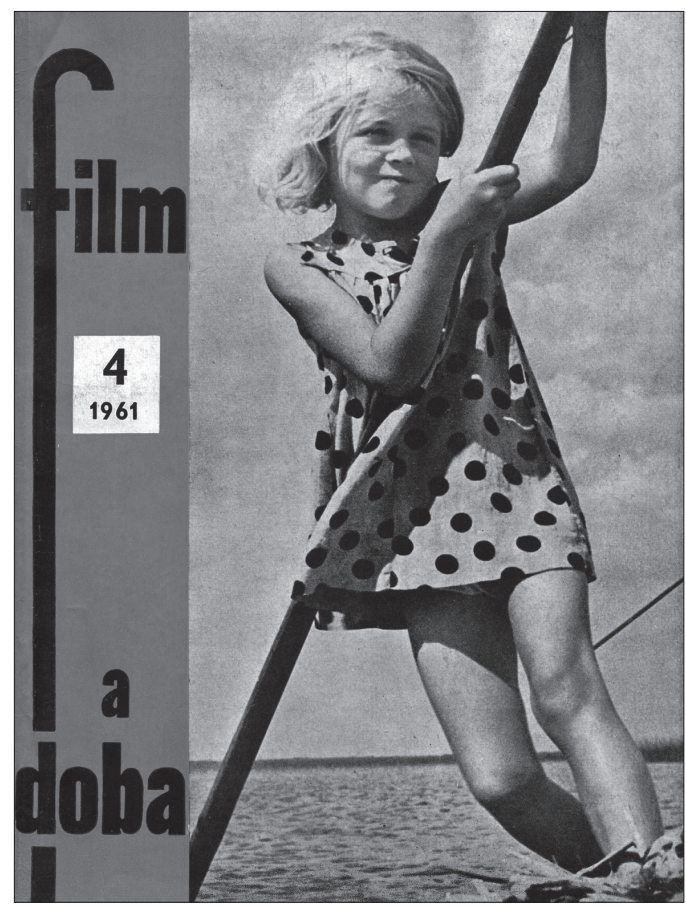

Laima on the cover of a Czech magazine.

[27] S. Beauvoir, "Ištrauka iš prisiminimų knygos 'Viską apsvarsčius", trans. Vytautas Bikulčius, Literatūra ir menas 2009, January 9, p 12.

[28] The Lithuanian partisan war between 1944 and 1953 was the strongest and longest armed anti-communist resistance in Central and Eastern Europe. The primary goal of these people that retreated to the forests (which gave rise to them being named the "Forest Brothers") was to resist the joining of Lithuania to the Soviet Union, and try to regain independence and a democratic Lithuania. The partisans were defeated by the NKVD army in 1953. Some separate groups still operated until the 1960 s.
The theme of the difficulties of post-war life is also reflected in the equally mesmerizing and multi-layered work Nobody Wanted to Die by Vytautas Žalakevičius. The film was made at Lithuanian Film Studios in 1964. It would show Lithuania to the world and change the history of Lithuanian cinema.

The individual in the face of history: a ballad of suffering

The thaw of life in Lithuania in 1965 was marked by an important event in its cultural life. World-famous intellectuals visited this occupied country that was closed to foreigners. Simone de Beauvoir and Jean Paul Sartre came for a one-week visit to Lithuania. A special showing of Vytautas Žalakevičius' Nobody Wanted to Die, an example of the art of Soviet film, was arranged for these left-leaning French philosophers in Moscow before arriving to Vilnius. In her memoirs, Simone de Beauvoir emphasized that like Estonia, Lithuania was independent only during the interwar period, and the joining of these countries to the USSR gave rise to many hardships and resistance by the people. Further on in her memoirs, she observed, "Those groups of partisans were depicted by a rather interesting Lithuanian film, and it didn't seem that today the Russians would be very well-liked in Lithuania." [27] That was what Žalakevičius' film talked about: the victory of the new government in Lithuania, the partisan resistance, and Soviet-occupied Lithuania.[28] The film Nobody Wanted to Die is a special film, criticized by historians from an ideological perspective, multi-layered, and masterfully created thanks to the work of the director, cameraman, and actors. The ambiguous narrative perspective of Žalakevičius' film provided two different and hidden ways of understanding the film, which turn the film into an intriguing task for the viewer. Let us try to decode what we might call the "historical truth" of this Lithuanian film. In this analysis, we will focus our attention on places in the film marked by symbols and their associations in Lithuanian culture and mythology. 


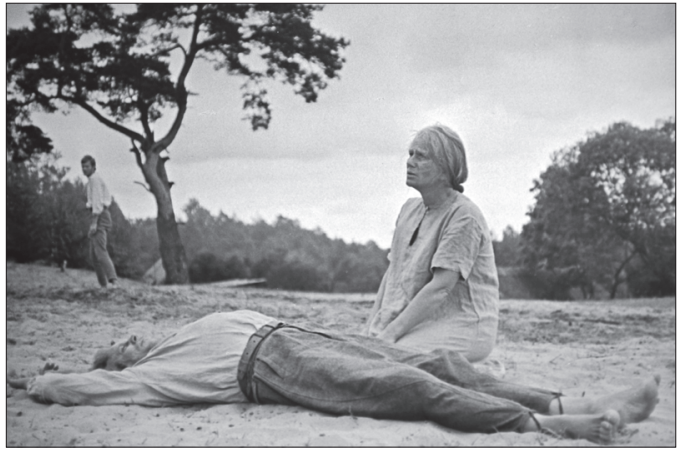

The wife of Lokis, weeping for her beaten husband, Nobody Wanted to Die, directed by V. Žalakevičius.

Žalakevičius decided to depict the postwar conflict in Lithuania, when there were still partisan groups operating in the forests (called by propaganda as "groups of nationalists and bandits") fighting against the Soviet regime. The film talks about the Lokys family, in which the father, who is the head of the collective farm, is killed. When his four sons learn of his death, they go to their village seeking revenge for his spilled blood. The four sons, who are as strong as oaks, look for the head of the partisans in the forest, who has the mythological name of Aitvaras. A fierce battle then ensues, taking place in the idyllic surroundings of a village, full of mythological symbols.

\section{The unique space of myths and symbols}

The film is set in a village surrounded by an ancient and magnificent forest. Žalakevičius chose to film in the secluded Lithuanian village of Zervynai (there was still no electricity there at the time), located in a forest in the southern region of Dzükija, where the 19th-century houses are complete with old-fashioned household items. By placing events painful for the Lithuanian nation in a village surrounded by oaks, the director emphasized the role of the village as a space that was deeply rooted in the Lithuanian consciousness. The image of the oak forest in the film also expresses its aesthetic tone. The village cloaked in fog, the magnificent forest with its ancient oaks, and the melancholy and tranquillity penetrating the setting express the longing of people for the moral order that was destroyed by the Soviet regime.

The road to and from the village has a sacral symbolic meaning. In the film, we often come across the visual motif of a roadside chapel with the figure of a Pensive Christ at a crossroads in the forest. It appears briefly in three places in the film and accentuates the plot. The roadside chapels, with their figures of Christ sitting with his head leaning on his hand, are often found in forests in Lithuania, and are considered a unique Lithuanian sign. One finds them along roads, masterfully carved, with a little roof above a sitting Christ. The little sculptures of the Pensive Christ are still made today for Lithuanian cemeteries as a symbol of pain and suffering. Before the Second World War, the Lithuanian philosopher Stasys Šalkauskis wrote: "By depicting the Pensive Christ, the Lithuanian nation also depicted its fate. The incredible pain and at the same time tranquillity, close to resignation, is characteristic not only for Christ, but for the depicter the whole of the Lithuanian nation." [29] Accenting the idea of the film, Žalakevičius adds "One could say that the Pensive Christ was the start of everything." [30] The sacral, cultural and visual symbol of the Pensive Christ, seen in the film as a roadside chapel in an oak alongside the road, became a metaphor in Lithuania, a symbol of the pain and sadness of the Lithuanian nation.

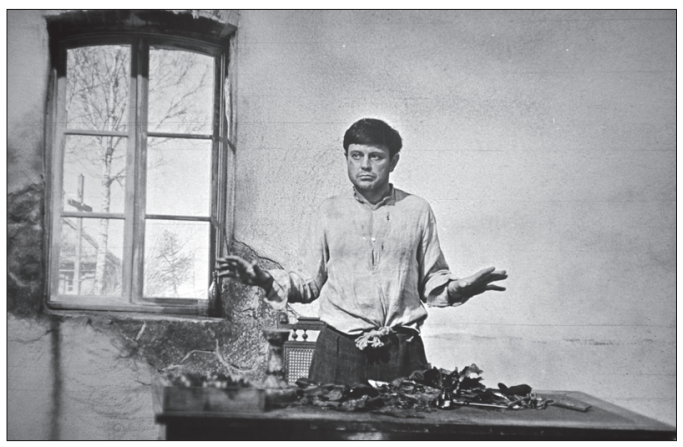

Vaitkus - Donatas Bainionis, Nobody Wanted to Die, directed by V. Žalakevičius.

[29] S. Šalkauskis, "Lietuviai -istorinių paradoksų tauta”, Krantai 1989, no. 6, pp.18-30.

[30] V. Žalakevičius, op.cit., p. 253. 
The film's text is supplemented with scenes, dialogues, and gestures with various meanings. One eloquent example is the sign of a crucified Christ, which is made by Vaitkus (played by Donatas Banionis) when he takes over the duties as the head of a collective farm; another is the USSR coat-of-arms that is hanging crooked, and which no one hurries to straighten. The severity and impulsiveness of the four brothers, strong as oaks, clearly contrasts with the timid figure of the First Secretary and Soviet uniforms. The main roles in the film were performed by Žalakevičius' favorite Lithuanian actors, Donatas Banionis, Bronius Babkauskas, Algimantas Masiulis, and Laimonas Noreika, as well as the Estonian actor Bruno Oja. This group of actors would form the future core of the Lithuanian school of acting.[31]

In the last fragment, filled with tension and shot in the spirit of an American western, Aitvaras (played by Laimonas Noreika) is shot in a barn. The bullet strikes him in the chest, and he, looking heroically and proudly at his killer, Bronius Lokys, says to him and the viewers, looking into Aitvaras' eyes, "You don't know what pain [it is]. You don't know." At the time, these words were on the lips of many Lithuanians and bore witness to the unspoken pain of thousands of young people who fought and died for Lithuania's freedom.

Decoding the film's symbolic content allows us to better understand the essence of the work. The ideological tone of the film's plot (the communist government against the bandit nationalists) is not the only way to interpret the film's theme. It is supplemented by the apparent secondary elements that are hidden in the film's formal structure, and the characters' gestures and dialogues. In the background of the film's

[31] The film's success was essential in popularising the actors playing in it. Andrei Tarkovsky saw Donatas Banionis after the film's premiere and offered him a role in the film Solaris. It is interesting to note that Lithuanian actors often played Westerners, as Soviet directors saw Western, aristocratic traits in Lithuanians. They often played Wehrmacht or SS soldiers. primary propaganda plot, we observe a drama of the Lithuanian nation that is conveyed believably through dialogues and images that are full of symbols from Lithuanian ethnic culture. These elements emphasize the film's dualistic meaning, expressed in the words of the film's protagonist: "It was spring and no one wanted to die." In describing his film, Žalakevičius often repeated that it could be understood as a ballad where everything is made up, except for the suffering. Suffering is the strongest motif of the film, and became a fundamental motif in Lithuanian cinema.

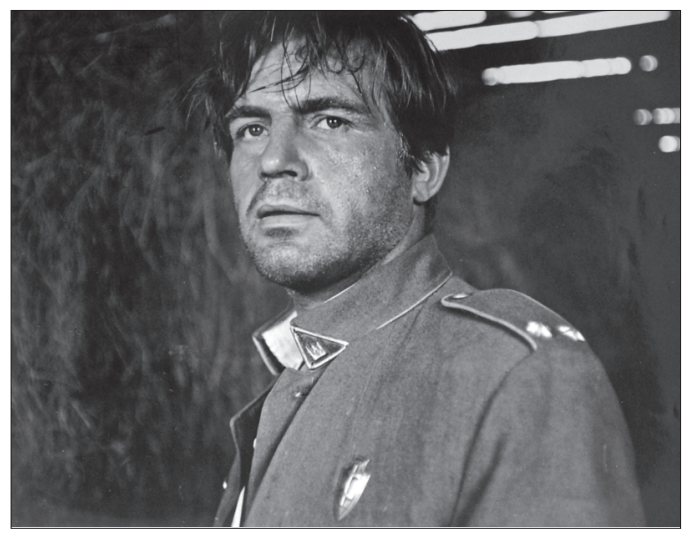

Aitvaras - the leader of the Lithuanian partisans, Nobody Wanted to Die, directed by V. Žalakevičius.

If we understand it correctly, Žalakevičius' work bears witness to the dramatic fate of a time period and nation in the vortex of history.

The motif of a conquered Lithuania and partisans fighting against Soviet rule appears once again as a dominant part of the composition in the 1966 film A Staircase to the Sky by Raimondas Vabalas and the 1968 lyrical film Feelings by Almantas Grikevičius and Algirdas Dausa. These films were a metaphor for Lithuania's difficult past. The story of everyday life in post-war Lithuania is told in a lyrical, melancholic, and at the same time dramatic fashion, along with the fate of a society torn apart ideologically. Czech critics wrote about this period, saying "The motifs of dissillusionment, sorrow, melancholy, and insecurity one 
in a way the mark of Lithuanian cinema of those years." [32]

The theme of the Lithuanian partisans becomes crucial. It was the art favored most by Soviet ideology, which now began to speak about forbidden themes, such as the Lithuanian resistence movement. No other form of art spoke had spoken on this theme before. In Almantas Grikevičius' film, based on Žalakevičius' script, we hear a patriotic dialogue about Lithuania's captivity that is poken at the dinner table among a few people that are preparing to escape to Sweden:

- We're eating for perhaps the last time in our land [...]

- In our land.

- Aren't you thinking of returning?

- Will we return only to a free Lithuania?

- It's understandable, that we might not see it.

- Then our children will return.

- Unless Lithuania disappears by then.

- How?

- It will be destroyed physically, lose its identity-disappear [...]

- While emigration is alive, while there are patriots alive in our homeland [...].

The censors banned the film, and it was put on the shelf. It is important to note that in 1995 Lithuanian film critics recognized it as the best Lithuanian film of all time.

The dramas of the history of the nation made by Žalakevičius, Grikevičius, and Vabalas, which depicted a conquered society and a repressive Soviet system, raises associations with the prominent works of the Polish, Czech, Slovak, and Hungarian New Wave. According to Russian director Andrei Konchalovsky, it is no coincidence that directors and students of the VGIK learned the fortitude from these films to talk about the tragic fates of their nations: "The different political thought process came not from the West, but from our Socialist camp first of all from Poland, from Hungary, from Czechoslovakia [...]. The very first world-class anti-Soviet film was Ashes and Diamonds. And afterwards came great films from Czechoslovakia”, remembers the famous Russian director.[33]

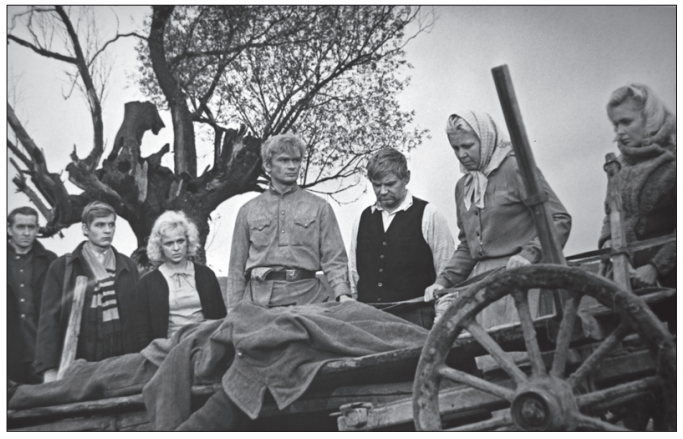

A family gathered around their deceased son, Staircase to Heaven, directed by R. Vabalas.

Comparing Lithuanian film to the Hungarian school of film and Polish cinematography of the 1960 s, one can notice quite a few analogies. In all three cases we are talking about artistic forms that are marked by a maturity of thought that attempted to understand societies that had undergone psychological traumas. The common experience of these cultures coming face-to-face with totalitarianism and the after-effects of captivity became the primary stimulus for the work of these young directors. The film The Round-Up/Szegénylegények (1965) by Hungarian director Miklós Jancsó uses an allegorical language to speak about the terror after the suppression of the 1956 Uprising in Budapest, which painfully affected the Hungarian intellegentsia. The first Hungarian films that revealed the essence of the communist totalitarianism of the 1940 s and 1950 s was István Gaál's The Green Years/Zöldár (1965) and Zoltán Fábri's Twenty Hours/Húsz óra (1965). Somewhat earlier, in Andrzej Wajda's film Ashes and Diamonds, metaphorical language tells a story about the end of the war, when a young man tries to assassinate a representative of the communist government, and the realistically depicted fate of the Warsaw insur-

[32] M. Liehm, A.J. Liehm, The Most Important Art: Eastern European Film After 1945, trans.

Kác a Polácková-Henley, Berkeley, London 1977, p. 329.

[33] A. Konchalovsky, Niskije istiny, Moskva 200o, p. 54. 
gents who died in the city's sewers in his film Canal/Kanat, 1956). In Czech director Evald Schorm's film The Seventh Day, the Eighth Night/Den sedmý, osmá noc (1969), allegorical language is used to speak about the invasion of the Eastern Bloc into Czechoslovakia in 1968. The Poles depict their tragic post-war experience through the tragedy of a young man (Ashes and Diamonds), the Czechs through a farce (The Seventh Day, the Eight Night), the Hungarians through a historical drama (The Round-Up), and the Lithuanians through a family drama (Nobody Wanted to Die). These shared post-war realities, the experience and pain of political captivity were essential factors in that Lithuanian, Polish, Czech, Slovakian, and Hungarian filmmakers could start speaking about these fundamental issues of their nations. Wajda has observed that

Eastern European cinema, thanks to the most conscientious and patriotically minded directors, expressed the aspirations of these nations to living an independent political life. The directors of former socialist countries learned to create images

[34] A. Wajda, O polityce, o sztuce, o sobie, Warszawa 200o, p. 36.

[35] V. Žalakevičius, op.cit., p. 56.

[36] E. Gyertyan, "W oczekiwaniu na nowe kroki Miklósa Jancsó”, trans. H. Kuźniarska, Kino 1977, no. 139 , p. 50-51.

[37] J. Žalman, op.cit., p. 61.

[38] Central European film directors often refer to elements of Christianity. We can find these elements in Štefan Uher's The White Dove, Evald Schorm's The Seventh Day, the Eighth Night, Andrzej Wajda's Ashes and Diamonds, and Vytautas Žalakevičius' Nobody Wanted to Die. Christian motifs dominate in Jerzy Kawalerowicz's Mother Joan of the Angels/Matka Joanna od Aniołów and Karel Kachyna's Night of the Bride /Noc nevěsty. There is a figure of the Pensive Christ in the film Nobody Wanted to Die, while there is an upside-down cross in Ashes and Diamonds. In the final scene of The Seventh day, the Eight Night, a "Jesus" is thrown into river, and a "Mary Magdalene" becomes a victim of violence. These symbols bear witness to a world of shattered values, the loss of spiritual balance, and become a silent metaphor for a captive society. that were based on national traditions, their native literature, which from a glance were not threatening, however in reality became the dynamite that blew up the walls of our isolation.[34]

One should also keep the rules of the Soviet system in mind. While the literary script was carefully checked, the image did not raise any greater controversies or discussions. Ideology expressed itself in words, which is why the censor corrected each suspect sentence, while film was and is an art of imagery. Thus, a poetic language of imagery filled with metaphors was born out of this system of Soviet censorship. As Žalakevičius stated, "an artist can live just fine picking 'forbidden fruits' and be understood thanks to Aesopian language." [35] Such a system of bans helped to form a unique cinematic language. It was precisely this visual form (often called Aesopian language), which allowed Central European cinematography to experiment with the content of films. In talking about his films, Miklós Jancsó said that "Using a small amount of words, showing things in the kind of situations where they would be something else." [36] Slovak director Štefan Uher was certain that it was only thanks to the innovative forms that one can express oneself, while as for the films, you needed to read in-between the lines.[37] The films' language, marked by a specific manner of speaking without words, opened up the image of the story, which the Soviet regime tried to hide and falsify. The directors, having grown into their tradition, culture and history, fought for their fate with images, not words.[38] Lithuanian film in the 1960 s was not as radical in its form as Vera Chytilova's experiments with form, or the films of Juraj Jakubisko, which are full of carnivalesque elements, or have the ironic and sober view of reality, like the work of Miloš Forman, Jiří Menzel, and Andrzej Munk. The figure of Maciek from Wajda's film Ashes and Diamonds was relatable for the painful discussions of history in Lithuanian films: a romantic with a tragic fate, dying in convulsions on a pile of trash. The struggle of the neo-romantic hero and the film's space, where "spirit is the most 
important" [39] became main idea of the films Nobody Wanted to Die, Feelings and Staircase to Heaven.

The primary value of these works was the understanding of history through the prism of the individual and his difficult decisions in a demoralized society. It is here where history expresses itself, not in marching masses, impressive battalions, revolutionary circles, and passionate speeches, but in the shape of individuals and people suffering through their existence. The individual's moral choices in the face of history became the crux of the narrative in the films Nobody Wanted to Die, A Staircase to Heaven, and Feelings. One could consider this crux to be the main trait in Lithuanian cinema that ties it with the tradition of Central European cinema. In analysing Central European cinema, Dina Iordanova emphasized that "The defining contributions of East Central European film to world cinema are films concerned with the discourse on morality and history, with the relationship between the private and the public." [40] This link between morality and history also became the dominant theme in 1960 s Lithuanian film.[41]

However, these fresh winds that blew in did not last long in film. The Soviet invasion of Czechoslovakia in 1968 brought an end to this creative thaw. Artistic ambitions began to waver, and people began to leave. Andrzej Wajda went abroad for a few years, while Roman Polanski left for good. Miloš Forman and Ivan Passer left Czechoslovakia. Lithuanian Film Studios also felt the effects of people leaving: the famous script writer and artistic director Vytautas Žalakevičius left for Moscow. Paradoxically, he was unable to realise any films after his successful film Nobody Wanted to Die. As late as 1973, Žalakevičius wrote in a letter: "There is anathema and fire in my soul... My minister spoke with Ermash and the CK [Central Committee]. In order to tie me to my trough. They won't manage to do that, instead
I will most likely go to Wajda in Poland." [42] However, his plans were not fulfilled. Instead of leaving for Poland, which was spiritually close to him, he went to Mosfilm. He spent 10 years there making films acceptable for the Soviet propaganda machine commissioned by the state.

The censors heavily edited Almantas Grikevičius' films Feelings and Saduto tuto// Sadūto tūto due to unacceptable formalism. Raimondas Vabalas' June, The Beginning of Summer /Birželis, vasaros pradžia sat on the shelf, even after six different versions of the script were made. The biggest loss for Lithuanian cinema was the stoppage of work on a historical epic about the Prussian uprising led by Herkus Mantas. The film, directed by Almantas Grikevičius, was of great scope, with battle scenes and naturalistic imagery that were filmed in a very life-like way. The censors rejected it, and, at the same time, ruined the director's life.[43] Raimondas Vabalas told Russian film critic Valery Fomin that

When in 1959 Gyvieji didvyriai appeared and Lithuanian cinema had started, we thought 'here it's early spring, the shoots will break through.' And then an earthquake happened. Yes, so that's what happened to us, $[\ldots]$ an earthquake. All we could do is stop making films. Or die of hunger." [44]

Frost had bit after the thaw.

[39] M. Janion, "Egzystencja ludzi i duchów. Rodowód wyobraźni filmowej Andrzeja Wajdy”. [in:] Zło i fantazmaty, ed. M. Czermińska, Prace wybrane, vol. 3, Kraków 200, p. 398.

[40] D. Iordanova, op.cit., p.2.

[41] Maryla Hopfinger wrote also about the domination of the problem of morality in Polish film, and the choice of the individual in the fact of historical conflicts (cf. M. Hopfinger, Adaptacje filmowe utworów literackich: problemy teorii $i$ interpretacji, Wrocław 1974, p. 143.

[42] RGALI, f. 2996, opis 1, ed. 185, p. 1.

[43] The film about the Prussian uprising was finished by director Marijonas Giedrys.

[44] R. Vabalas, "To chto s nami sdelali,- eto zemliatresenye", Kinoforum 2002, no. 4, p. 34. 


\section{Conclusion}

Despite the ideological influence of certain institutions and Soviet censorship, 1960s Lithuanian cinema was able to maintain a common artistic line with Central European film. This was possible due to ties between directors, common inspirations and the common history that joined the countries of Central Europe together. The similarities of themes in Lithuanian, Hungarian, and Polish film was also heavily influenced by a similar history, which gave rise to existential trauma. Bolesław Michałek says that

It still seems that similar mechanisms are at work
in the Central and Eastern European space. It is
precisely these that provided a common trait to the
art of this region. The best films of these countries
functioned as an instruments for the recognition
of the struggle for subjectivity, the sovereignty of
the individual, the fright for his fundamental rights
and choice of freedoms. They come out against the
doctrine, the goal of which was to manipulate peo-
ple and history.[45]

These experiences and attitudes can also be seen in the work of Lithuanian directors of the time.

Lithuanian cinema of the 1960 s with its visual poetics and game of cinematic forms is akin to the tradition of the Czech New Wave; it is also linked with Hungarian and Polish cinema by the shared need to talk about the difficult post-war history, and a refined cinematic language-Aesopian language-in talking about national identity. The limits of their creative work led to the forming of a new aesthetic for films, described by the term "Aesopian language". With the help of allegories and metaphors, a dialogue was created with viewers about their culture, undistorted history, and past.

We could risk making a hypothesis that the real hearth of ideas that changed the face of the period and cinema was stoked not in the West, but in the cultural sphere of Central Europe.

[45] B. Michałek, "Kino Środkowo-Europejskie, kino Europejskie", Kino 1990, no. 5, p. 13.

[46] J. Kroutvor, Europa Środkowa: anegdota i historia, trans. J. Stachowski, Izabelin 1998, p. 33.
In Poland, Hungary, and Lithuania, cinema used made use the chance to use its cultural experience to create a unique cinematic language. The experience of the Soviet system and the desire to protest with the artistic means of cinematic expression brought the directors of Lithuania and Central and Eastern Europe together. At the time in this part of Europe, the people coming of age began protesting against the domination of the Soviet regime with creative manifestos. It was their way of expression, and they were incomparable and unique. A common trait among the cinema movements of the 1960 s was that in a relatively short period, a plethora of new and talented directors appeared. These young people gained experience at creative workshops created at film studios. They were interested in the same themes, and the life shared between people who were united by common historical and moral experiences, and the consequences of historical change. It was here that freedom, democracy, and independence were talked about.

The Czech writer Milan Kundera's famous essay "The Tragedy of Central Europe", in which he wrote about the shared spirit of the region, re-ignited discussion about Central Europe, while Czesław Miłosz a quarter of a century earlier in his book Native Realm noted the historical experience that united the countries of Central and Eastern Europe. As we look for common traits in the cinema of Central European countries, history once again becomes the primary refrain. As Josef Kroutvor states: "History for a Central European is first of all the sum of bitter experiences." [46] We can say that this spiritual kingdom and the historical experience joining the countries of Central Europe, this shared painful experience, binds together the directors of Lithuania, Poland, the Czech Republic, Slovakia, and Hungary. It is not possible to negate the existence of this spiritual territory in film, or lessen its meaning, as it helped to form the basis for the fall of the communist system. 